\title{
Molecular analysis of human T-cell lymphotropic virus type 1 and 2 (HTLV-1/2) seroindeterminate blood donors from Northeast of Iran; evidence of proviral tax, env, and gag sequences
}

\author{
Delaram S Zanjani ${ }^{1 *}$, Majid Shahabi ${ }^{2}$ \\ From 15th International Conference on Human Retroviruses: HTLV and Related Viruses \\ Leuven and Gembloux, Belgium. 5-8 June 2011
}

\section{Background}

Human T-cell lymphotropic virus type 1 and 2 (HTLV$1 / 2$ ) Western blot indeterminate results are a problem of blood banks in endemic areas.

\section{Materials and methods}

To determine the prevalence of HTLV-1/2 infection among indeterminate donors, we analysed 130 cases from Mashhad, an HTLV-1/2 endemic area in northeast of Iran.

\section{Results}

The most frequent Western blot bands were GD21 alone (37.2\%) followed by rgp46-2 alone (32.1\%). We further tested 40 available DNA samples of these cases by PCR for viral sequences; tax, gag, and pol and found 5 cases $(12.5 \%)$ to be positive for two or three HTLV-1 genes. There were no significant age, sex, and blood group differences between PCR positive and PCR negative cases. Among PCR positive individuals, the most prevalent Western blot bands were variable combinations of rgp46-1, GD21 and gp21 bands. The mean of optical density (OD) of enzyme linked immunosorbent assay (ELISA) test were was significantly higher in PCR positive individuals. The frequency of rgp46-1 band was also significantly higher in PCR positive cases, compared to PCR negative ones.

\footnotetext{
* Correspondence: delteh2003@yahoo.com

${ }^{1}$ Mashhad transfusion service, Research center of Iranian Blood Transfusion Organization, Mashhad, Iran
}

Full list of author information is available at the end of the article

\section{Conclusions}

The majority of HTLV-indeterminate donors lack HTLV provirus and therefore are not considered infected. However, in some cases with higher ODs in ELISA test and seroreactivity to env proteins; in particular rgp46-1 and GD21 may be indicative of infection and need further evaluation by molecular methods.

\section{Author details \\ 'Mashhad transfusion service, Research center of Iranian Blood Transfusion Organization, Mashhad, Iran. ${ }^{2}$ Research center of Iranian Blood Transfusion Organization (IBTO), Tehran, Iran.}

Published: 6 June 2011

doi:10.1186/1742-4690-8-S1-A66

Cite this article as: Zanjani and Shahabi: Molecular analysis of human Tcell lymphotropic virus type 1 and 2 (HTLV-1/2) seroindeterminate blood donors from Northeast of Iran; evidence of proviral tax, env, and gag sequences. Retrovirology 2011 8(Suppl 1):A66.

Submit your next manuscript to BioMed Central and take full advantage of:

- Convenient online submission

- Thorough peer review

- No space constraints or color figure charges

- Immediate publication on acceptance

- Inclusion in PubMed, CAS, Scopus and Google Scholar

- Research which is freely available for redistribution

Submit your manuscript at www.biomedcentral.com/submit
( Biomed Central

\section{Ciomed Central}

